Sebila Haskić, prof. pedagogije

\title{
DJELOVANJE PROSVJETNO-PEDAGOŠKOG ZAVODA U BIHAĆU OD 1960. DO 1992. GODINE
}

Sažetak

Pregled djelovanja Prosvjetno-pedagoškog zavoda u Bihaću u periodu od osnivanja 1960. do 1992. godine omogućio je potpunije sagledavanje njegove uloge u nastavnom procesu. $S$ obzirom da su prosvjetno-pedagoški zavodi ustanove čija je osnovna djelatnost da prate $i$ vrednuju rezultate rada svih odgojno-obrazovnih ustanova, od predškolskog do srednjeg obrazovanja, javila se želja da se istraži uloga $i$ doprinos ovog zavoda u sferi obrazovanja $i$ nastave. Cilj istraživanja je teorijsko proučavanje djelatnosti Prosvjetnopedagoškog zavoda u Bihaću od osnivanja, tj. od 1960., do 1992. godine. Ovdje je pažnja isključivo usmjerena na hronološki prikaz rada Zavoda, transformacije, profesionalnu i stručnu djelatnost $i$ pedagoge $e^{l}$, koji su djelovali i radili u Prosvjetno-pedagoškom zavodu $u$ tom periodu.

\section{UVOD}

Polazeći od činjenice da prosvjetno-pedagoški zavodi imaju veliku ulogu u odgoju i obrazovanju, nameće se i potreba da se što više piše o njihovom djelovanju i njihovom doprinosu na tom polju.

Prosvjetno-pedagoški zavod u Bihaću je upravo jedan od pomenutih, zbog toga i predstavlja problem ovog istraživanja. U istraživanju se polazi od činjenice da je Prosvjetno pedagoški zavod u

Naziv pedagog potječe od grčkih riječi: pais, paidos - 'dječak'; ago, agein 'voditi'; pidagogus - 'rob koji je vodio dječaka na javna mjesta kod nastavnika i brinuo o njegovoj sigurnosti'. U Pedagoškoj enciklopediji se pominje pet različitih značenja ovog pojma a to su:

'svaki onaj koji se bavi odgojem', 'samo oni koji se profesionalno bave odgojem',

'samo oni koji predaju pedagogiju kao nastavni predmet',

'samo oni koji se bave proučavanjem odgoja'. 
Bihaću djelovao, prije svega, u veoma teškim materijalnim uslovima, teškim radnim uslovima itd. Prije nego bilo što kažem o strukturi rada, somenut ću određene poteškoće koje su se javile na samom početku prikupljanja podataka.

Istražujući rad i razvoj Prosvjetno-pedagoškog zavoda $u$ Bihaću, došla sam do zaključka da oni nemaju potpunu i sređenu dokumentaciju, koja bi meni bila polazna osnova za dalji rad. Ono što me hrabrilo je činjenica da su živi određeni ljudi, odnosno savjetnici i direktori koji su radili u PPZ-u Bihać. Prva osoba s kojom sam stupila u kontakt je prof. dr. Osman Ramić, dugogodišnji radnik PPZ-a Bihać. Trenutno živi i radi kao dekan Pedagoškog fakulteta u Bihaću. Spomenut ću i prof. Mehmeda Džanića, također dugogodišnjeg radnika PPZ-a Bihać, a u vremenu 1994-1997. godine bio je i direktor Zavoda. U razgovoru s njima moglo se dobiti dosta bogatih i iscrpnih informacija o radu i razvoju PPZ-a Bihać za period njihovog rada $\mathrm{u}$ Zavodu. Neophodno je spomenuti i prof. Zrinka Šantića, koji je radio i sad trenutno radi u Pedagoškom zavodu u Bihaću kao prosvjetni savjetnik, prof. Vasu Bukaricu, također dugogodišnjeg radnika Zavoda, zatim mr. Fikreta Midžića, direktora Arhiva, zatim prof. Ismeta Botonjića i mnoge druge.

Ovaj rad je sačinjen iz devet tematskih cjelina odnosno poglavlja, a neka od tih poglavlja sadrže i određene podnaslove.

$\mathrm{Na}$ samom početku, u teorijskom pristupu problemu, govori se općenito o pedagoškim zavodima, o njihovoj strukturi, ulozi, djelovanju i zaslugama.

Dalje sam se osvrnula na metodologiju istraživanja koja obuhvata problem istraživanja, predmet, cilj, zadatke i metode istraživanja.

U četvrtom poglavlju se govori o razvoju prosvjetnopedagoške službe, djelovanju i određenim transformacijama.

U petom poglavlju je posebno obrađena djelatnost PPZ-a Bihać, koja je izložena u četiri tematska kruga, a svako od njih je posebno objašnjeno. To su:

1. Uvid u odgojno-obrazovni rad,

2. Analitička i stručno-istraživačka djelatnost,

3. Stalno stručno usavršavanje,

4. Saradnja sa organizacijama. 
U šestom poglavlju sam se posebno osvrnula na instruktivnopedagoški rad prosvjetnih savjetnika u Prosvjetno-pedagoškom zavodu za period koji sam istraživala.

Sedmo poglavlje obuhvata pedagoge i prosvjetne savjetnike koji su radili u PPZ-u Bihać od osnivanja. Radi preglednosti sam ih pobrojala po odsjecima u kojima su radili, a to su tri odsjeka:

1. Odsjek za predmetnu nastavu,

2. Odsjek za razrednu nastavu,

3. Odsjek za pedagoško-psihološka pitanja.

$* * *$

U radu su posebno obrađeni pedagoški i drugi pojmovi koji se spominju kroz rad. Također, korištene su određene skraćenice kao npr.:

- SIZ - Samoupravna interesna zajednica,

- PPZ - Prosvjetno-pedagoški zavod,

- RPZ - Republički pedagoški zavod,

- SRBiH - Socijalistička republika Bosna i Hercegovina,

- SPPZ - Sreski prosvjetno-pedagoški zavod,

- SL - Službeni list,

- SFRJ - Socijalistička federativna republika Jugoslavija.

\section{TEORIJSKI PRISTUP PROBLEMU}

U Pedagoškoj enciklopediji, u redakciji dr. Nikole Potkonjaka i dr. Petra Šimleše, može se naći objašnjenje pojma Zavodi za unapređivanje vaspitanja i obrazovanja u SFRJ. Kaže se da su to "specijalizovane organizacije koje obavljaju poslove i zadatke prosvjetno-pedagoške službe". ${ }^{2}$ Začetak prosvjetno-pedagoške

\footnotetext{
${ }^{2}$ Prosvjetno-pedagoška služba u djlelatnosti odgoja i brazovanja obavlja poslove praćenja i unapređivanja odgojno-obrazovnog rada te nadzire ostvarivanje ciljeva i zadataka odgoja i obrazovanja. Područje djelovanja prosvjetno-pedagoške službe je cjelokupni odgojno-obrazovni sistem, što podrazumijeva sve društveno organizirane oblike odgoja i obrazovanja djece i omladine, obrazovanja odraslih, kao i proučavanje utjecaja raznih faktora na odgoj mladih. Rad na poslovima unapređivanja odgoja i obrazovanja, društva u cjelini i svestranog razvoja ličnosti, te praćenje ostvarivanja posebnog društvenog interesa u odgoju i obrazovanju dolazi do izražaja prije svega putem stalnog osposobljavanja odgojno-obrazovnih radnika. Vidi: Potkonjak, N. i šimleša, P. (1989) Pedagoška enciklopedija, str. 271.
} 
službe javlja se već u 19. vijeku u instituciji školskog nadzora vezanoga uz državne organe. Institucija školskog nadzora postojala je $\mathrm{u}$ istom statusu i između dvaju ratova u Kraljevini Jugoslaviji. Nakon oslobođenja, od 1945. do 1950. postojala je u našoj zemlji prosvjetna inspekcija $^{3}$ u sastavu državne uprave, također $\mathrm{s}$ naglašenom funkcijom školskog nadzora. Već od 1950. do 1957. god. traže se oblici koji će više odgovarati društvenom razvoju, tako da se osim nadzora pojačava zahtjev za pedagoško-instruktivnim radom. Od 1954. do 1956. god. u svim su republikama osnovani zavodi za unapređivanje školstva a na razini Jugoslavije Savezni zavod za proučavanje prosvjetnih i školskih pitanja.

Naziv prosvjetno-pedagoška služba javlja se prvi put u Općem zakonu o školstvu 1958. godine. Na temelju tog zakona republike i pokrajine posebnim zakonima reguliraju rad prosvjetno-pedagoške službe, osnivaju se zavodi za školstva na razini republika i drugih društveno-političkih zajednica.

Kroz prošlost se mogu sresti i nazivi kao što su Prosvjetnopedagoški zavod, Pedagoški zavod, Zavod za unapređivanje vaspitnoobrazovnog rada, Sreski prosvjetno-pedagoški zavod (Bihać), Međuopćinski pedagoški zavod (Bihać). Najčešće su uređeni posebnim zakonom, koji se različito naziva (Zakon o unapređivanju vaspitno-obrazovnog rada, Zakon o organizaciji i radu zavoda za unapređivanje vaspitanja i obrazovanja, Zakon o prosvjetnopedagoškoj službi, Zakon o pedagoškoj službi itd.). Verifikovani su kao stručno-pedagoške organizacije ili naučno-stručne organizacije. Zavodi se bave poslovima i zadacima od posebnog društvenog interesa.

${ }^{3}$ U Pedagoškoj enciklopediji u redakciji dr. Nikole Potkonjaka i dr. Petra Šimleše navodi se sljedeća definicija ovog pojma. "Prosvjetna inspekcija obavlja nadzor nad primjenom zakona i drugih propisa, društvenih dogovora i samoupravnih sporazuma, samoupravnih općih akata, propisanih mjera, standarda i normativa kojima se uređuje djelatnost odgoja i obrazovanja te poduzima preventivne mjere $\mathrm{i}$ akcije radi sprečavanja kršenja zakonitosti u toj djelatnosti. Prosvjetna inspekcija nadzire naročito uvjete rada i djelovanja škola i drugih organizacija u kojima se provodi odgoj i obrazovanje, normative i standarde za ostvarivanje odgojnoobrazovnih programa, nastavne planove i udžbenike, upise u škole i na fakultete, stručnu spremu nastavnika i drugih odgojno-obrazovnih radnika, izbor nastavnika i drugih radnika, ispitivanje i ocjenjivanje učenika, izdavanje svjedodžbi o stečenom obrazovanju, odgojne mjere te uvođenje propisane evidencije i dokumentacije." (str. 
Osnovna im je funkcija da unapređuju odgojno-obrazovni rad i nadziru ostvarivanje cilja $i$ zadataka odgoja ${ }^{4}$ i obrazovanja ${ }^{5} u$ predškolskom, osnovnom i srednjem obrazovanju.

Općinski i međuopćinski zavodi obavljaju poslove i zadatke uglavnom u predškolskom, osnovnom i zajedničkim predmetima u srednjem obrazovanju. Bave se pretežno praktičnim pitanjima unapređivanja odgojno-obrazovnog rada $i$, u tom smislu, pomažu odgojno-obrazovnim organizacijama $u$ ostvarivanju odgojnoobrazovnog procesa, pri izradi godišnjih programa rada $^{6}$, pripremi nastavnika, predlažu mjere za poboljšanje uslova rada i sl.

Osnovni zadaci su im:

1. praćenje, analiza i ocjenjivanje kako se ostvaruju planovi i programi odgojno-obrazovnog rada i predlaganje mjera da se oni usavršavaju;

2. obavljanje stručno-pedagoškog uvida i nadzora;

3. istraživanje oblika, metoda ${ }^{7}$ i sredstava za praćenje efikasnosti nastavnog procesa;

${ }^{4}$ U Pedagoškoj enciklopediji se navodi sljedeća definicija pojma odgoj: " /.../ Odgoj bi se mogao odrediti kao društvena praksa ljudi, kao društveno-pedagoški proces razvoja čovjekove individualne i društvene osebenosti. /.../ Odgoj je proces osposobljavanja ljudi za ljudski smislen i stvaralački način reprodukcije i produkcije osnovnih uvjeta njihove egzistencije: rada, društvenih odnosa i slobodnog vremena.

${ }^{5}$ Obrazovanje je pedagoški proces u funkciji obogaćivanja ljudske spoznaje. Obuhvaća usvajanje određenog sustava znanja, formiranje praktičnih umijeća i navika. Obrazovanje je djelatnost, aktivnost, pedagoški proces, ali istovremeno označava i rezultat tog procesa, osobinu ličnosti. Kao rezultat obavlja se najčešće u školama i na fakultetima, pod vodstvom nastavnika-odgajatelja.

6 U Osnovnoškolskoj pedagogiji, autora Refika ]atića i Osmana Ramića, između ostalog navodi se sljedeće objašnjenje: "Godišnji program rada škole je školski dokument kojim odgojno-obrazovna ustanova reguliše svoj rad u cjelini, u svakom programskom i organizacijskom dijelu, i predstavlja zbir i sintezu cjelokupnih aktivnosti škole u toku jedne godine." U Pedagoškoj enciklopediji u redakciji dr. Nikole Potkonjaka i dr. Pere Šimleše navodi se sljedeće: "Godišnji program najčešće sadrži cilj i zadatke /.../, vrstu i obim odgojno-obrazovne djelatnosti, organizaciju rada, nosioce zadataka, potrebno radno vrijeme i sl. Na osnovi godišnjeg programa izrađuju se programi rada svih nosilaca zadataka i operacionalizacija po polugodištima ili užim vremenskim intervalima (tromjesečno, mjesečno)."

${ }^{7}$ U pedagoškoj enciklopediji se navodi sljedeće objašnjenje: "Metoda (od grč. Methodos=put, način- općenito znači smišljen ili ustaljen postupak usmjeren na postizanje nekog cilja.... ili ustaljen ili smišljen način obavljanja neke djelatnosti." 
4. organizovanje stručnog i pedagoškog obrazovanja i usavršavanja nastavnika i pomaganje školama da tu aktivnost bolje organizuju.

5. praćenje i podsticanje rada na profesionalnoj orijentaciji ${ }^{8} .{ }^{9}$

Pojedini zavodi prate primjenu udžbenika i priručnika i predlažu mjere za usavršavanje; rade stručno-analitičke i istraživačkorazvojne poslove; istražuju metodologiju ${ }^{10} \mathrm{i}$ instrumente vrednovanja rada nastavnika i odgojno-obrazovnih organizacija.

Osnivači općinskih zavoda su bile općine i samoupravne interesne zajednice (SIZ), ${ }^{11}$ međuopćinskih (regionalnih) zavodaskupštine općina

8 Profesionalna orijentacija je odabir najpogodnijih poslova, zanimanja za pojedine osobe prema njihovim sposobnostima, sklonostima i interesovanjima ali $\mathrm{i}$ mogućnostima.

9 Potkonjak, N. i Šimleša, P. (1989), Pedagoška enciklopedija, Beograd, Zavod za udžbenikei nastavna sredstva.

10 U Pedagoškoj enciklopediji se između ostalog navodi da se metodologija sistematski bavi metodama. To je posebna disciplina koja proučava logičke operacije i istraživačke postupke u sklopu znanstvene spoznaje. Metodologija se dijeli na opću (koja proučava one oblike misaonih aktivnosti i spoznajne postupke što su zajednički svim znanostima) i posebne metodologije (koje proučavaju organizaciju istraživačkog rada $u$ svakoj posebnoj znanosti te čine pomoćnu disciplinu te znanosti).

${ }^{11}$ SIZ osnovnog obrazovanja i vaspitanja Bihac, kao subjekt planiranja, svoj plan razvoja zasniva na kumulativnim pokazateljima potreba škola, kao nosioca planiranja, zatim potreba i interesa mjesnih zajednica, društveno-političkih zajednica i rada u cjelini, polazeći pri tome od realnih mogućnosti osnovnih organizacija udruženog rada materijalne proizvodnje, kao stvaraoca novih vrijednostii društvenih dobara, da iz svog dohotka izdvajaju dio sredstava za podmirenje potreba ove društvene djelatnosti. U izradi plana SIZ-a polazilo se od zakonima utvrđenih prava i obaveza, zatim potreba i mogućnosti razvoja, a osnove za prikazivanje ukupnih i pojedinačnih obaveza proizilaze iz:

1. Odredaba Zakona o udruženom radu,

2. Smjernica za izradu plana razvoja i

3. Dogovora o osnovama Društvenog plana razvoja općine Bihać za period 1981-1985. godine, kojim su utvrđene sljedeće obaveze SIZ-a osnovnog obrazovanja i vaspitanja Bihać, kao segmenta jedinstvenog plana razvoja:

- Obezbijediti potrebna sredstva za rješavanje materijalnih uslova rada i kadrovkih problema,

- Obezbijediti potpuni obuhvat školskih obveznika osnovnim obrazovanjem,

- Utvrditi mjere koje obezbjeđuju veći kvalitet i efikasnost svih vidova odgoja i obrazovanja 
i samoupravnih interesnih zajednica, a republičkih i pokrajinskih zavoda-izvršno vijeće republike/pokrajine.

Djelatnost zavoda finansirala se uglavnom iz dvaju izvora: iz budžeta i sredstava odgovarajućih samoupravnih interesnih zajednica i slobodnom razmjenom rada.

Nadzor nad zakonitošću rada općinskih zavoda obavljala je skupština općine, međuopćinskog (regionalnog) zavoda - skupštine više općina, a nad zakonitišću rada republičkog/pokrajinskog zavodaizvršno vijeće republike/pokrajine.

$\mathrm{Na}$ poslovima prosvjetno-pedagoške službe u zavodima rade prosvjetni savjetnici ${ }^{12}$ - stručni kadrovi sa visokom stručnom spremom i najmanje pet godina radnog iskustva $u$ nastavi $i$ objavljenim radovima. Biraju se na četiri godine, odnosno ponovo se biraju svake četiri godine. Zavodima rukovodi direktor.

- Dosljednije pristupiti ostvarivanju ustavnog principa o slobodnoj razmjeni rada,

- Provesti oblike samoupravnog interesnog obrazovanja koji su u skladu sa zakonskim rješenjima i utvrđenim političkim stavovima,

- Sredstva za ostvarivanje dogovorenih ciljeva i zadataka obezbijediti slobodnom razmjenom rada zavisno od obima i kvaliteta zadovoljenih zajedničkih obrazovnih potreba i interesa i ekonomskih mogućnosti korisnika obrazovnih usluga,

- Da osigura sredstva za dogradnju škola,

- Da posveti posebnu pažnju izjednačavanju uslova školovanja i prema vlastitom programu opremanja škola da osigura vrijednost opreme i sredstava. (SIZ osnovnog obrazovanja i vaspitanja, (1980), Plan razvoja za period 1981-1985 godine).

12 U Pedagoškoj enciklopediji se navodi sljedeće objašnjenje: "Prosvjetni savjetnik je radnik u djelatnosti dgoja i obrazovanja koji obavlja poslove prosvjetno-pedagoške službe, tj. prati i unapređuje odgojno-obrazovni rad i nadzire ostvarivanje ciljeva i zadataka odgoja i obrazovanja. U ostvarivanju svojih zadataka prosvjetni radnik, individualno i u sklopu radnih grupa, surađuje neposredno $\mathrm{s}$ radnim organizacijama i nastavnicima, osposobljavajući ih za primjenu rezultata i dostignuća pedagoške teorije i prakse, za uvođenje zakonskih, programskih, tehnoloških i metodičkih inovacija, unapređivanje samoupravne organizacije i odnosa u odgojno-obrazovnim organizacijama, povezivanje škole sa njenom društvenom, kulturnom i radnom sredinom i rješavanje problema koji se pojavljuju u praksi odgoja i obrazovanja. Zbog toga prosvjetni savjetnici neposredno proučavaju rad, pojave i probleme u odgoju i obrazovanju, uz primjenu znanstvenih metoda istraživanja, uopćavaju i sistematiziraju rezultate svog rada." 


\section{METODOLOGIJA ISTRAŽIVANJA}

Metodologija pedagoškog istraživanja je pedagogijska disciplina koja proučava putove pedagogijske spoznaje, osobito spoznajno-teorijske osnove, metode, postupke i tehnike od kojih se polazi, odnosno koje se upotrebljavaju pri konstituiranju pedagogijske teorije i ustanovljavanju znanstvenih zakona na tom području.

U tom smislu i ja ću u ovom dijelu rada reći nešto konkretnije o problemu istraživanja, predmetu, cilju, zadacima, metodama, postupcima i instrumentima istraživanja.

\subsection{Problem istraživanja}

Polazeći od činjenice da prosvjetno-pedagoški zavodi imaju veliku ulogu u odgoju i obrazovanju, nameće se i potreba da se što više piše o njihovom djelovanju i njihovom doprinosu odgoju i obrazovanju.

Prosvjetno-pedagoški zavod u Bihaću je upravo jedan od pomenutih, zbog toga i predstavlja problem ovog istraživanja. U istraživanju se polazi od činjenice da je Prosvjetno-pedagoški zavod u Bihaću djelovao i sad djeluje u veoma teškim, prije svega, materijalnim uslovima, teškim radnim uslovima itd.

\subsection{Cilj istraživanja}

Cilj istraživanja je teorijsko proučavanje djelatnosti Prosvjetno-pedagoškog zavoda u Bihaću od osnivanja tj. od 1960. do 1992. godine. Ovdje je pažnja isključivo usmjerena na hronološki prikaz rada Zavoda, transformacije, profesionalnu i stručnu djelatnost i pedagoge koji su djelovali i radili u Prosvjetno-pedagoškom zavodu $\mathrm{u}$ tom periodu.

\subsection{Zadaci istraživanja}

Osnovni zadaci istraživanja na osnovu postavljenog predmeta $i$ cilja istraživanja su:

1. Pronaći i proučiti dokumentaciju koja se odnosi na problem istraživanja; 
2. Za potrebe istraživanja pripremiti odgovarajuće instrumente kao što su protokoli intervjua;

3. Analizirati programe rada i izvještaje;

4. Istražiti ko su bili prosvjetni savjetnici i direktori koji su radili u Zavodu u pomenutom peridu;

5. Stupiti u kontakt sa osobama koje su nekad radile u Zavodu i doći do relevantnih podataka;

6. Sve prikupljene podatke do kojih se dođe obraditi i interpretirati.

\subsection{Metode istraživanja}

Metode koje su korištene u ovom istraživanju su:

1. historijska metoda

2. metoda teorijske analize

3. metoda proučavanja pedagoške dokumentacije

4. deskriptivna metoda

\subsubsection{Historijska metoda}

Ova metoda ima izuzetno veliki značaj za proučavanje ideja, a također i ustanova u raznim histirijskim etapama. Historijska metoda otkriva genezu pojedinih problema koji se javljaju u određenim vremenskim razdobljima. Izvori kojima se služi istraživač mogu biti: historija pedagogije ${ }^{13}$, djela klasika pedagoga, monografije ${ }^{14}$ i $_{\text {in }}$ studije koje obrađuju pojedine pedagoške probleme, zakonska akta (ustav, zakoni, propisi), zapisnici, izvještaji, djelatnost raznih udruženja, programi odgojno-obrazovnog rada, novine, časopisi, autobiografije, anali $^{15}$, memoari ${ }^{16}$, pisma, bilješke nastavnika,

\footnotetext{
13 Historija pedagogije je znanstvena pedagoška disciplina koja proučava razvoj odgoja i obrazovanja u prošlosti u vezi s promjenama u društvu: društvenu uslovljenost (u klasnom društvu i klasni karakter) odgoja i obrazovanja, njihov utjecaj na razvijanje društva; područja, oblike, ciljeve i zadatke, sadržaj, organizaciju i metode odgoja i obrazovanja; nove pedagoške ideje i djelovanje njihovih nosioca na odgojno-obrazovnu praksu te subjekte, ustanove, sredstva i sve pojave koje su u vezi s odgojem i obrazovanjem.

14 Monografija je naučni rad koji obrađuje neko pojedino pitanje, jednu temu.

5 Anali (lat annus= godina) - godišnjaci; opis historijskih događaja po godinama, vremenskim slijedom.
} 
književni materijal, školske zgrade, fotografije i drugi ostaci koji mogu poslužiti kao dokument o odgojno-obrazovnom radu u jednom periodu. Good i Scates navode tri osnovna procesa historijske metode:

1) Prikupljanje podataka, uključujući razmatranje izvora, kao što su dokumenti i spomenici primarne i sekundarne građe i sistem bilježenja;

2) Kritika podataka, uključujući proces eksterne i interne kritike;

3) Pisanje historije (historiografija), uključujući probleme organizacije građe, općih filozofskih pogleda i specifičnih škola.

Da bismo razumjeli djelovanje Prosvjetno-pedagoškog zavoda u Bihaću, potrebno je da poznajemo njegovu historiju i etape kroz koje je prošao u svom dugogodišnjem razvoju. Porijeklo riječi historija upućuje nas na traženje znanja i istine, na iznalaženje. Historija je svaka cjelovita priča ili opis prošlih događaja ili činjenica, pisan u duhu kritičkog traženja potpune istine. ${ }^{17}$

\subsubsection{Metoda teorijske analize}

Metoda teorijske analize jedna je od metoda pedagoškog istraživanja koja se služi pretežno dedukcijom kao logičkometodološkim postupkom u pedagoškom istraživanju. Osnov za njenu primjenu su već utvrđena pedagoška i druga saznanja izražena u uopštenom vidu (pojmovi, zakonitosti, teorije $\mathrm{i}$ dr.), stečena primjenom drugih istraživačkih metoda i postupaka. Važnost primjene metode teorijske analize u pedagoškom istraživanju jest u njezinoj mogućnosti da uoči složene aspekte pedagoške stvarnosti, da iz toga izdvoji bitne karakteristike i međusobne odnose, te zakonitosti razvoja pedagoških pojava. Izvori za primjenu ove metode su pedagoška literatura, kao i udžbenici s tog područja, zatim radovi u vezi sa opštim društvenim stavovima o odgoju i obrazovanju. Izvjesnu ulogu torijske analize nalazimo $u$ svakom metodološki adekvatno zasnovanom i provedenom istraživanju.

16 Memoari (fr. Memoire) - literarno djelo u obliku bilješki kojima je autor bio suvremenik ili u kojima je sudjelovao.

17 Good i Scates (1967), Metode istraživanja u pedagogiji, psihologiji i sociologiji, Rijeka, Otokar Keršovani. 


\subsubsection{Metoda proučavanja pedagoške dokumentacije}

Pedagošku dokumentaciju čini skup sačuvanih podataka koji su u vezi s problemima odgoja. Sve odgojno-obrazovne organizacije dužne su voditi pedagošku dokumentaciju i evidenciju o učenicima te o ostvarivanju svojih zadataka i programa. Pedagoški dokumenti koji se najčešće proučavaju su školske svjedodžbe, dnevnici, pisane "karakteristike" o radnim i drugim osobinama učenika. Većina izvornih dokumenata koji se obrađuju u pedagoškim istraživanjima su pisani dokumenti (kako štampani tako i oni rukom pisani) te crteži, grafikoni, sheme. Analiza sadržaja ovih dokumenata može biti kvalitativna i kvantitativna. Zapravo i nema pedagoškog istraživanja u kojem se ne bi javljala analiza pedagoških dokumenata. Ova metoda je posebno značajna u historijskim istraživanjima gdje se sama pojava ne može direktno proučiti pa joj treba pristupiti indirektno preko postojećih dokumenata. Međutim, metoda proučavanja pedagoške dokumentacije ne služi samo za historijska istraživanja nego i za analizu pedagoške sadašnjice, a na nekim područjima školske problematike daje i dragocjeni materijal za procjenu budućih kretanja. Osnovna prednost ove metode je što se dokumenti mogu upotrijebiti dosta vremena nakon njihova nastanka, a nedostatak jeste česta nepouzdanost i netočnost podataka u dokumentima.

\subsubsection{Deskriptivna metoda}

«Deskriptivna metoda u istraživanju odgoja i obrazovanja predstavlja skup znanstveno-istraživačkih postupaka s kojima se opisuju pojave u odgoju i obrazovanju, tj ispituje se stanje, a time i njihove osobine, a bez obzira na njihove uzroke.»» ${ }^{18}$

Karakteristike naučne primjene deskripcije možemo sažeti u slijedeće dvije osnovne tačke:

1. Rad na deskripciji u naučnom istraživanju specifično je usmjeren prema iskorištavanju rezultata za naučnu spoznaju, a to znači da je usmjeren prema generalizaciji, prema pronalaženju bitnih zajedničkih karakteristika istovrsnih odnosno srodnih pojava;

18 Vladimir Mužić (1999) Uvod u metodologiju istraživanja odgoja i obrazovnja, Zagreb, Educa, str.43. 
2. Taj se rad stoga ne zaustavlja na opisivanju onog što jest, ne zadovoljava se prikupljanjem i sređivanjem podataka, nego obuhvaća i uspoređivanje, suprotstavljanje kao i vrednovanje te interpretacije podataka.

Deskripcija shvaćena kao naučna metoda obuhvaća uz prikupljanje, obradu i prezentaciju podataka još i njihovu interpretaciju, izvođenje zaključaka u raznim pravcima, uključujući i ukazivanje na način kako bi se na osnovu tih rezultata moglo ili trebalo usavršiti odgojno-obrazovnu praksu.

\section{RAZVOJ PROSVJETNO-PEDAGOŠKE SLUŽBE}

Do 1960. godine poslove prosvjetno-pedagoške službe obavljali su nadležni organi za prosvjetu NR BiH i sreskih narodnih odbora. U svom djelovanju ti organi imali su, u skladu s tadašnjim sistemom upravljnja, više inspekcijski a manje instruktivni karakter.

Zakonom o prosvjetno-pedagoškoj službi (SL. NR BiH 50/60) utemeljena je prosvjetno-pedagoška služba radi proučavanja i unapređivanja odgojno-obrazovnog rada $u$ odgojno-obrazovnim ustanovama osnovnog i srednjeg obrazovanja. Jedan od važnih zadataka službe je bio nadzor nad izvršavanjem propisa o organizaciji i radu odgojno-obrazovnih ustanova.

Iz ovako definisane nadzorne funkcije u djelokrugu rada proizašla su prava i dužnosti prosvjetnih savjetnika, što je u praksi rezultiralo administrativnim načinom djelovanja prosvjetno-pedagoške službe (uvid u cjelokupan rad odgojno-obrazovne ustanove, pismeno ili usmeno upoznavanje s nalazom i mišljenjem u formi izvještaja, izdavanje pismenog naloga itd.).

Zakonom o prosvjetno-pedagoškoj službi iz 1964. godine (SL. SR BiH 42/64) određenije je naglašena i diferencirana nadzorna funkcija (stručno-pedagoški nadzor nad izvođenjem nastave i drugih oblika odgojno-obrazovnog rada, nadzor nad izvršenjem propisa $u$ organizaciji i izvođenju odgojno-obrazovnog rada u školama kao i obaveza najmanje dvaju pregleda svih odgojno-obrazovnih ustanova u toku jedne školske godine). Djelokrug rada službe ostao je uglavnom nepromijenjen kako u pogledu ingerencija savjetnika, tako i u pogledu cjelokupnog načina rada službe.

Zakon o prosvjetno-pedagoškoj službi (SL SR BiH 10/73) izostavlja nadzornu funkciju nad izvršenjem propisa o organizaciji i 
izvođenju odgojno-obrazovnog rada, jer je ova funkcija, posebnim propisima (Zakon o prosvjetnoj inspekciji, SL SR BiH37/71, Zakon o izmjenama i dopunama Zakona o prosvjetnoj inspekciji, SL SR BiH 39/73. i Zakon o prosvjetnoj inspekciji, SL SR BiH 28/77.), prenesena u nadležnost prosvjetne inspekcije dok je stručni nadzor nad organizacijom i izvođenjem nastave i dugih oblika odgojnoobrazovnog rada ostao i dalje u nadležnosti prosvjetno-pedagoške službe. Istovremeno je djelatnost službe, u duhu društvenih potreba, proširena novim sadržajima, u smislu čvršćeg vezivanja Zavoda za rad Samoupravne interesne zajednice i odgojno-obrazovnih ustanova. Ovim Zakonom se određuju poslovi od posebnog značaja za neprekidno usavršavanje odgojno-obrazovnog sistema (vrednovanje nastavnih planova i programa, inovacije u nastavi, permanentno obrazovanje ${ }^{19}$ ).

Oblast stručnog usavršavanja regulisana je Zakonom o stalnom stručnom usavršavanju nastavnika (SL SR BIH 6/76). Ovaj zakon je na nov način usmjerio rad prosvjetno-pedagoške službe (pomoć pripravnicima i mentorima, organizacija stručnih seminara, rad stručnih aktiva i drugo) i dao znatne poticaje naporima za stalno stručno usavršavanje u odgojno-obrazovnim organizacijama.

Zakon o unapređivanju vaspitno-obrazovnog rada (SL SR BIH 28/81) utvrđuje sve subjekte unapređivanja odgojno-obrazovne djelatnosti, a time i dosadašnju prosvjetno-pedagošku službu stavlja u nov položaj zamjenjujući njenu stručno-nadzornu funkciju saradničkim odnosom u stručnom i naučno-istraživačkom radu.

\section{DJELATNOST PROSVJETNO-PEDAGOŠKOG ZAVODA BIHAĆ}

Djelatnost Prosvjetno-pedagoškog zavoda u Bihaću može se izložiti u četiri tematska kruga:

1. Uvid u odgojno-obrazovni rad,

2. Analitička i stručno-istraživačka djelatnost,

3. Stalno stručno usavršavanje,

19 Neki autori za ovaj pojam upotrebljavaju termin "doživotno obrazovanje". U Pedagoškoj enciklopediji se može naći sljedeće objašnjenje: "Pojam permanentnog obrazovanja ima svoja dva osnovna opšta značenja: kao koncepcija (skup ciljeva, principa, stavova $i$ orijentacija o permanetnom obrazovanju) $i$ skup obrazovnih aktivnosti koje se preduzimaju radi obrazovanja čovjeka tokom njegovog čitavog radnog vijeka pa i dalje sve do kraja života." 
4. Saradnja sa organizacijama.

\subsection{Uvid u odgojno-obrazovni rad}

Središnje mjesto u poslovima uvida u odgojno-obrazovni rad, kojim je u programima i njihovoj realizaciji svake godine odvajano preko 30\% ukupnog radnog vremena PPZ-a Bihać, pripada stručnim pregledima odgojno-obrazovnog rada, tj. instruktivno-pedagoškom radu i savjetodavnom radu savjetnika. U skladu sa zakonom, dogovorima na nivou prosvjetno-pedagoške službe u Republici i potrebama nastavno-odgojne prakse, PPZ Bihać je u toku višegodišnjeg djelovanja uložio znatne napore u obavljanju pregleda organizacije rada, redovnih i ostalih oblika nastave u odgojnoobrazovnim ustanovama. Savjetnici su u sklopu redovnih posjeta odgojno-obrazovnim ustanovama pružali stručnu pomoć nastavnicima $\mathrm{u}$ formi instrukcija i savjeta. Ove poslove pratila je i praksa informiranja odgojno-obrazovnih ustanova $\mathrm{u}$ formi zapisnika, izvještaja, informacija, stručnih zabilješki, koji su sadržavali elemente analize i korektivne preporuke za odgojno-obrazovni rad.

Za ilustraciju ove djelatnosti, ostvarene na raznim nivoima odgoja i obrazovanja (predškolske ustanove, osnovne, škole, srednje škole) i vidovima djelatnosti u odgojno-obrazovnim ustanovama (organizacija rada, redovna i ostali vidovi nastave), navodi se, npr., da je u toku 1980. godine jednokratnim i višekratnim pregledima organizacije rada i odgojno-obrazovnog procesa, $u$ pojedinačnim, grupnim ili ekipnim posjetama prosvjetnih savjetnika i brojnih saradnika, obuhvaćeno pet predškolskih odgojno-obrazovnih organizacija, 23 odgojno-obrazovne organizacije u razrednoj nastavi, 38 odgojno-obrazovnih organizacija u predmetnoj nastavi osnovne škole, 11 odgojno-obrazovnih organizacija u srednjem usmjerenom obrazovanju.

Stručni pregledi u kontekstu instruktivno-pedagoškog rada i poslovi koji su ga pratili proizilazili su iz zakonskih zahtjeva i društvenih potreba za nadzornom funkcijom prosvjetno-pedagoške službe. Međutim, iako je u ovom pogledu Zavod učinio mnogo napora, on objektivno nije mogao udovoljiti svim zahtjevima odgojnoobrazovnih ustanova, SIZ-ova i društveno-političkih zajednica i zbog nedostatka savjetnika i zbog složene problematike u ovoj oblasti djelovanja prosvjetno-pedagoške službe. 
Osim neposrednog uvida $\mathrm{u}$ odgojno-obrazovni rad preko stručnih pregleda PPZ Bihać je uložio znatne napore i u praćenju drugih vidova rada u odgojno-obrazovnim ustanovama (popravni, završni, vanredni i drugi ispiti, verifikacija škola i sl.).

\subsection{Analitička i stručno istraživačka djelatnost}

Značajno mjesto u radu Zavoda zauzimala je izvještajnoinformativna i stručno-istraživačka djelatnost, kojoj je godišnjim programima rada namjenjivano $30 \%$ raspoloživog vremena. Bavljenje ovim poslom započelo je 1968. godine a intenzivirano je od 1973. godine kad je i Zakonom o prosvjetno-pedagoškoj službi (član 8, tačka 5, 11, 12 i 13) ova djelatnost posebno naglašena kao izraz potreba odgojno-obrazovnih ustanova, samoupravno-interesnih zajednica odgoja i obrazovanja, društveno-političih zajednica i republičkih organa i organizacija.

U informativno-analitičkoj djelatnosti Zavoda posebno mjesto zauzimaju izvještaji, informacije i analize o uspjehu učenika krajem prvog plugodišta i krajem školske godine te izvještaji, informacije i analize o pripremljenosti škola za početak školske godine koji su, u jednom periodu djelovanja Zavoda, rađeni posebno za svaku samoupravnu interesnu zajednicu odgoja i obrazovanja. Pored ovih rađeni su i različiti informativno-analitički materijali o specifičnim pitanjima (opremljenost škola, problemi nastavnog kadra, provedena takmičenja učenika, pregledi nastave, modeli raznih sporazuma i pravilnika, informacije o vanrednim ispitima i dr.). Samo u 1980. godini, npr., napisana su 32 takva materijala.

Bez obzira na to što na nivou Republike nije bilo jedinstveno organizovanog pristupa istraživačkoj djelatnosti, Zavod u Bihaću se, kao i drugi regionalni zavodi, u okviru svojih kadrovskih i materijalnih mogućnosti, svake godine bavio i stručno-istraživačkim radom. (Ovo su neki od problema koji su bili predmet ispitivanja: provjeravanje i ocjenjivanje učenika, samoupravljanje učenika, metode početnog čitanja i pisanja, književnojezička politika u BIH, funkcionalnost nastavnih sredstava, izrada testova znanja i modela planova nastavne građe i drugo.)

Sastavni dio ove djelatnosti bili su permanentno praćenje i vrednovanje udžbenika, priručnika i raznih didaktičkih materijala (s 
idejnog, stručnog i pedagoško-psihološkog aspekta) kao i recenzije jednog broja udžbenika.

\subsection{Stručno usavršavanje}

Prosvjetno-pedagoški zavod u Bihaću uložio je znatne napore i na stalnom stručnom usavršavanju nastavnika, koje ima presudno značenje za unapređivanje odgojno-obrazovnog rada. Djelovanje Zavoda na ovim poslovima naročito je inenzivirano nakon donošenja Zakona o stalnom stručnom usavršavanju nastavnika, tako da je u ovu svrhu Zavod namjenski rezervisao oko $20 \%$ raspoloživog radnog vremena.

Posebno aktuelne zadatke u realizaciji sadržaja stručnog usavršavanja nastavnika, prosvjetni savjetnici su dobili poslije izlaska Zakona o stalnom stručnom usavršavanju nastavnika 1976. godine. U odabiranju sadržaja rada na stručnom usavršavanju nastavnika, Zavod je nastojao da se pridržava zakonskih odredbi. Zavod se koristio onim oblicima rada za koje je smatrao da će biti najefikasniji i da najbolje odgovaraju uslovima u kojima rade škole na području regije kao što su:

1. pomoć školama u osposobljavanju pripravnika za samostalan odgojno-obrazovni rad,

2. učešće u radu stručnih aktiva,

3. organizacija seminara i savjetovanja.

U okviru cjelokupnih nastojanja na stalnom stručnom usavršavanju, individualnom usavršavanju nastavnika, posvećena je posebna pažnja. Napori savjetnika usmjereni u ovom smislu rezultirali su izradom stručnih programa individualnog usavršavanja nastavnika, konsultacijama za izbor i pripremu stručnih tema, izradom bobliografije stručne literature i sl. Posebno mjesto zauzima stručni rad savjetnika s pripravnicima i mentorima na realizaciji programa pripremanja i polaganja ispita osposobljenosti za samostalan odgojnoobrazovni rad. U ispitnim komisijama kao ispitivači stručnog dijela ispita angažirani su prosvjetni savjetnici i stručni saradnici PPZ-a Bihać, što je pouzdan znak povjerenja odgojno-obrazovnih organizacija u stručni nivo savjetnika i saradnika Zavoda.

I oblicima kolektivnog stručnog usavršavanja PPZ Bihać je posvećivao znatnu pažnju. Ispunjavajući zahtjeve didaktičke teorije i potreba prakse, Zavod je radio na organiziranju i pripremanju brojnih 
stručnih aktiva nastavnika, direktora (predškolskih ustanova, osnovnih i srednjih škola) i školskih pedagoga. Tako su npr. samo u 1980. godini savjetnici i stručni saradnici ${ }^{20}$ Zavoda uzeli učešće u radu 75 sastanaka stručnih aktiva razredne nastave, 84 sastanka stručnih aktiva predmetne nastave u osnovnoj školi te 9 sastanka stručnih aktiva predmetne nastave u srednjoj školi. U obliku stručnih seminara, u predmetima osnovne i srednje škole za koje Zavod ima savjetnike, obrađeno je 13 tema, od kojih navodim samo neke: Alhamijado književnost, Tekstovna lingvistika i nastava izražavanja, Matematičko modeliranje i dr. Ovaj oblik kolektivnog stručnog usavršavanja obilježava se kao Pedagoški dani. U okviru tih dana eminentni stručnjaci i vanjski sardanici Zavoda su nastupali s posebnim temama a neke od njih sam već spomenula.

Pedagoške dane, kao jedan od oblika organizovanog stručnog usavršavanja, Zavod je počeo primjenjivati u 1980. godini.

Prema dogovoru sa direktorima predškolskog i osnovnog odgoja i obrazovanja, predstavnicima svih samoupravnih interesnih zajednica, te predstavnicima škola srednjeg usmjerenog obrazovanja, Pedagoški dani su održani u januaru i augustu mjesecu 1980. godine. Organizacija je bila slijedeća:

- plenarna predavanja za sve učesnike,

- sastanci stručnih aktiva.

$\mathrm{Na}$ plenarnim predavanjima obrađeni su sadržaji koji su predviđeni iz marksističkog idejno-političkog obrazovanja, obrazovanje za općenarodnu odbranu i društvenu samozaštitu i pedagoško-psihološko usavršavanje.

Ovdje je važno istaći $\mathrm{i}$ učešće prosvjetnih savjetnika na zimskim i ljetnim seminarima, koji su se održavali u Neumu, Splitu, Dubrovniku, Zadru itd., a organizator je bio Republički prosvjetnopedagoški zavod.

Zatim treba istaći i učešće savjetnika na Kongresima pedagoga, koji su se održavali na nivou Jugoslavije, BiH, Hrvatske itd. To su: Prvi kongres pedagoga Hrvatske, koji se održavao u Zadru

20 Radnik koji u odgojno-obrazovnim organizacijama učestvuje u realizaciji ili organizaciji odgojno-obrazovnog rada. Stručni saradnik organizira i obavlja stručne poslove vezane za odgojno-obrazovni rad, sudjeluje u nastavi pojedinih djelova struke ili uske stručnosti, organizira praktičan rad i stručnu praksu te obavlja druge poslove određene općim aktom znanstveno-nastavne organizacije. 
1981. godine, zatim Prvi kongres pedagoga BIH, koji se održavao u Neumu od 14 do 17.3.1990. godine, Četvrti kongres pedagoga Jugoslavije, koji se održavao u Beogradu 1977. godine, Peti kongres pedagoga Jugoslavije, koji se održavao u Sarajevu od 10. do 12. maja 1982. godine.

Dakako, osim na spomenutim oblicima kolektivnog usavršavanja savjetnici Zavoda su radili i na drugim oblicima usavršavanja nastavnika: stručne ekskurzije, škola skijanja, stručna obuka u kabinetu za fiziku, praktična predavanja pjedinih savjetnika, izložbe i sajmovi knjiga, učešće u organizaciji simpozija te organizacija posjeta simpozijima i kongresima pojedinih struka i sl.

\subsection{Saradnja sa organizacijama}

U sklopu djelovanja Zavoda znatan dio poslova obavljan je u saradnji s brojnim organima i organizacijama na području regije, Republike i zemlje. Zavod je kao dio jedinstvene prosvjetnopedagoške službe obavljao poslove od posebnog značaja za unapređivanje odgojno-obrazovnog sistema zajedno sa Republičkim prosvjetno-pedagoškim zavodom i regionalnim prosvjetnopedagoškim zavodima. Najznačajniji poslovi iz ovog dijela jesu učešće u izradi nastavnih planova i programa, provođenje javne rasprave, sumiranje rezultata javne rasprave kao i kontinuirano praćenje njihove primjene u odgojno-obrazovnom procesu.

Uključujući se u samoupravni preobražaj odgojno-obrazovnog sistema, Zavod je, u saradnji sa društveno-političkim organizacijama, samoupravnim interesnim zajednicama, radnim organizacijama privrednih i drugih društvenih djelatnosti i Privrednom komorom, bio jedan od organizatora javne rasprave na regiji u donošenju svih zakona i drugih dokumenata iz sfere odgoja i obrazovanja.

U cilju jačanja odgojno-obrazovne funkcije škole Zavod je, zajedno s odgojno-obrazovnim organizacijama i drugim saradnicima, pripremao i provodio razna takmičenja i smotre u znanju i stvaralaštvu učenika na školskom, općinskom, regionalnom i republičkom nivou. Među ovim aktivnostima posebno se ističu: Smotra znanja i stvaralaštva Titovim stazama revolucije, Male olimpijske igre, takmičenja historičara, lingvista, matematičara, fizičara, mladih tehničara, saobraćajno takmičenje i dr. 
U saradnji sa stručnom službom SIZ-a za zapošljavanje Zavod je pružao pomoć odgojno-obrazovnim organizacijama u profesionalnoj orijentaciji učenika osnovnih i srednjih škola.

$\mathrm{Na}$ mnogobrojnim drugim poslovima ostvarena je dobra saradnja s društveno-političkim organizacijama i zajednicama, samoupravnim zajednicama, Privrednom komorom, stručnim društvima, višim i visokoškolskim organizacijama.

\subsubsection{Zajednički poslovi s Republičkim i međuopćinskim pedagoškim} zavodima

U toku ovih godina Zavod je dio poslova obavljao u suradnji s Republičkim pedagoškim zavodom i ostalim međuopćinskim zavodima. Među tim poslovima dominantno mjesto zauzimali su sljedeći:

1. Zavod je aktivno učestvovao u izradi jedinstvenih elemenata $\mathrm{i}$ kriterija za vrednovanje rezultata rada osnovnih škola na nivou Republičkog pedagoškog zavoda,

2. Radio je na izradi Metodologije godišnjih programa rada škola na nivou Republike,

3. Sarađivao je na projektu Republičkog pedagoškog zavoda o Ostvarivanju kulturne i društvene funkcije osnovne škole,

4. Savjetnici su bili u stručnim timovima RPZ-a, gdje su davali svoj doprinos inoviranju i aktualizaciji programskih sadržaja nastavnih predmeta $\mathrm{i}$ vaspitnog rada škole u cjelini,

5. Savjetnici razredne nastave radili su na izgrađivanju jedinstvene metodologije za inovirani Nastavni plan i program, naročito u III razredu, a dat je doprinos u izradi metodologije instruktivno-pedagoškog rada i jedinstvene metodologije praćenja vrijednosti programa i udžbenika SR BiH,

6. Tokom 1990. godine, više nego ranije, ostvarena je dobra saradnja s ostalim međuopćinskim zavodima, posebno iz Banje Luke i Mostara o pitanju organizacije rada.

\section{INSTRUKTIVNO-PEDAGOŠKI RAD PROSVJETNIH} SAVJETNIKA

Kroz program rada Prosvjetno-pedagoškog zavoda u Bihaću, instruktivno-pedagoški rad je obuhvatao sljedeće oblike: 
1. informativni pregledi,

2. uže - stručni pregledi,

3. ekipni (opći) pregledi,

4. specijalni pregledi.

$\mathrm{S}$ informativnim pregledima su obuhvaćene sve ustanove na području djelovanja Prosvjetno-pedagoškog zavoda, a to su:

- osnovne škole s područnim odjeljenjima,

- srednje škole,

- đački domovi,

- radnički i narodni univerziteti i

- predškolske ustanove.

Uže - stručni pregledi su se obavljali prvenstveno kod:

- nastavnika koji nemaju odgovarajuću stručnu spremu,

- nastavnika s manjim radnim iskustvom i

- kod svih ostalih koji postižu slabije rezultate u nastavi.

Radi pregleda rada u predmetima za koje Zavod nema savjetnika, bili su angažovani vanjski saradnici (razni predmeti u stručnim školama, muzički odgoj, likovni odgoj, općetehničko obrazovanje, njemački i francuski jezik).

Ekipnim pregledima su bile obuhvaćene škole kojima je bilo neophodno pružiti odgovarajuću stručno-pedagošku pomoć $u$ organizaciji rada, izvođenju nastave i slično, ali i škole koje pokazuju naročito dobre rezultate $u$ nastavno-odgojnom radu $u$ cilju prikupljanja, uopštavanja i prenošenja pozitivnih iskustava.

Specijalni pregledi su se obavljali na zahtjev Osnovne zajednice obrazovanja, skupština općina i odgojno-obrazovnih ustanova.

Instruktivno-pedagoški rad prosvjetnih savjetnika u PPZ-u Bihać odvijao se preko raznih oblika njihovog djelovanja:

1. pregleda nastave i drugog vaspitno-obrazovnog rada,

2. individualnih kontakata s nastavnicima $u$ Zavodu,

3. učešća u provjeri osposobljenosti pripravnika za samostalan rad,

4. prisustvovanje ispitima u školama (završnim, vanrednim, popravnim) tj. pomoć u vrednovanju učeničkih postignuća,

5. primjena nastavnih metoda i oblika rada,

6. upotreba nastavnih sredstava,

7. uvid u nastavu na zahtjev odgojno-obrazovnih organizacija i drugih oblika neposrednog djelovanja savjetnika. 
Da bi zadovoljila svojoj osnovnoj funkciji, tj. unapređivanju odgojno-obrazovnog rada na svom području, Prosvjetno-pedagoška služba služila se različitim oblicima i načinima djelovanja.

Savjetnici su u sklopu redovnih posjeta odgojno-obrazovnim ustanovama, pružali stručnu pomoć nastavnicima u formi instrukcija i savjeta. Ove poslove pratila je i praksa informiranja odgojnoobrazovnih ustanova u formi zapisnika, izvještaja, informacija, stručnih zabilješki, koji su sadržavali elemente analize i korektivne preporuke za odgojno-obrazovni rad.

U sklopu ovih vidova saradnje s odgojno-obrazovnim organizacijama uvijek su bila naglašena određena tematska područja koja su u pojedinom pedmetu aktuelna i koja su bila naznačena u Godišnjem programu rada.

Uloga prosvjetnih savjetnika u intenziviranju nastavnog procesa ispoljavala se i u izradi instrumenata za vrednovanje učeničkih postignuća. Isto tako Zavod je, preko prosvjetnih savjetnika, pružio pomoć u izradi kriterija za vrednovanje osnovnih škola i vrednovanje realizacije godišnjeg programa rada predškolskih organizacija i učestvovao u vrednovanju rada osnovnih škola (Velika Kladuša).

Za ilustraciju ove djelatnosti, ostvarene na raznim nivoima odgoja i obrazovanja (predškolske ustanove, osnovne, škole, srednje škole) i vidovima djelatnosti u odgojno-obrazovnim ustanovama (organizacija rada, redovna i ostali vidovi nastave), navodi se npr. da je u toku 1980. godine jednokratnim i višekratnim pregledima organizacije rada i odgojno-obrazovnog procesa, u pojedinačnim, grupnim ili ekipnim posjetama prosvjetnih savjetnika i brojnih saradnika, obuhvaćeno pet predškolskih odgojno-obrazovnih organizacija, 23 odgojno-obrazovne organizacije u razrednoj nastavi, 38 odgojno-obrazovnih organizacija u predmetnoj nastavi osnovne škole, 11 odgojno-obrazovnih organizacija u srednjem usmjerenom obrazovanju.

Npr. u 1988. i 1989. godini intenziviranje odgojno-obrazovnog rada odnosilo se, prije svega, na jačanje rada stručnih aktiva, rada učeničkih organizacija i samoupravnih organa, i kao osnovno, na intenziviranje nastavno-odgojnog rada.

Ove djelatnosti su se ostvarivale putem:

1. saradnje s nastavnicima, školskim pedagozima i direktorima,

2. unapređivanja rada razrednika, 
3. rada učeničkih samoupravnih organa,

4. uvida u stručno usavršavanje nastavnika,

5. saradnje s roditeljima,

6. uvida u nastavni proces i sl.

U ovom radu najveća pažnja je poklanjana ostvarivanju nastavnih planova i programa, posebno u I razredu.

Prilikom posjeta nastavnicima posebno je ukazivano na relevantne sdržaje, literaturu i pružena pomoć $u$ planiranju programskih sadržaja.

$\mathrm{Na}$ području djelovanja Zavoda, savjetnici su pojedinačno, grupno ili ekipno posjetili oko $1 / 3$ škola, što je omogućavalo cjelovitije sagledavanje ostvarivanja nastavnih planova i programa $i$ poduzimanja mjera za cjelokupno unapređivanje odgojno-obrazovne djelatnosti škole. Praćeni su svi vidovi odgojno-obrazovnog rada: redovna nastava, dopunska, dodatna, fakultativna, slobodne aktivnosti učenika, rad učeničkih organizacija, rad stručnih organa, pedagoška dokumentacija i druga stručna pitanja.

Pored navedenog, razmatrana su i sljedeća pitanja:

1. Primjena raznovrsnih metoda i oblika rada u nastavi,

2. Upotreba nastavnih sredstava,

3. Izvođenje eksperimenata.

Naročita pažnja je bila posvećena radu s nadarenim učenicima (izbor nastavnih sadržaja, literature, metoda i oblika rada i sl.).

Zajedno sa školama, ili samostalno, savjetnici su pripremali razne nastavne listiće, upitnike, takmičarske zadatke, zadatke objektivnog tipa, testove, sheme, skice i sl.

7. PEDAGOZI I PROSVJETNI SAVJETNICI KOJI SU RADILI U PROSVJETNO-PEDAGOŚKOM ZAVODU BIHAĆ OD 1960. DO 1992. GODINE

\subsection{Direktori PPZ-a Bihać}

1. Adolf Andronik, prof. 1960-1965. godine

2. Diklić Zvonimir, prof 1965-1966. god. (Jedno vrijeme, a nakon njega funkciju vršioca dužnosti je preuzeo Hasan Delić.)

3. Veršić Marko, prof. 1967-1971. god. 
4. Kolaković Almasa, prof. 1971-1982. god. (Jedno vrijeme nakon nje su vršioci dužnosti bili Nikola Vučković i Vaso Bukarica.)

5. Ćazić Mirko, prof. 1983-1994. god.

6. Džanić Mehmed, prof. 1994-1997. godine (Od 1997. do 2000. godine Zavod je djelovao u sklopu Ministarstva obrazovanja.)

7. Botonjić Ismet, prof. 2000-2004. god.

\subsection{Prosvjetni savjetnici:}

\subsubsection{Odsjek za predmetnu nastavu:}

1. Mažar Dragan ( savjetnik za matematiku),

2. Bujanović Milan, prof. (savjetnik za biologiju),

3. Stojić Boško, prof. (savjetnik za historiju),

4. Rokvić Dušan (pr. savjetnik za matematiku i fiziku),

5. Kolaković Almasa, prof. ( savjetnik za biologiju),

6. Šabulić Ibrahim (prosvjetni savjetnik za geografiju),

7. Džanić Mehmed, prof. (prosvjetni savjetnik za sh/hs. jezik),

8. Dopuđa (rođ. Đukić) Milka, prof. (savjetnik za njemački jezik),

9. Eksle Velinka, prof. (prosvjetni savjetnik za ruski i engleski jezik),

10. Sukić Stanislav, prof. (prosvjetni savjetnik za fiziku),

11. Ramić Aziz, prof. (savjetnik za fizički odgoj),

12. Rašić Branka, prof. ( savjetnik za hemiju),

13. Čavkić Šefika, prof. ( savjetnik za sh/hs. jezik),

14. Galin Sava, prof. (prosvjetni savjetnik za matematiku),

15. Ramić Omer, prof. (savjetnik za fizički ogoj i odbranu i zaštitu),

16. Hadžihasanović Abdullah, prof. (savjetnik za OTOopćetehnički odgoj),

17. Hadžisadiković Nusreta, prof. ( savjetnik za poljoprivrednu oblast),

18. Omanović Ibrahim, prof. (savjetnik za engleski jezik),

19. Smiljanić Božo, prof. (savjetnik za geografiju),

20. Mr. Merdanić Halid ( savjetnik za biologiju),

21. Oručević Mehmed, prof. ( savjetnik za matematiku i fiziku),

22. Cvijetić Siniša, prof. (savjetnik za sh/hs. jezik), 
23. Bujanović Jasminka, prof. ( savjetnik za sh/hs. jezik).

\subsubsection{Odsjek za razrednu nastavu:}

1. Medić Stevo (savjetnik za razrednu nastavu),

2. Nakarada Vera (savjetnik za razrednu nastavu),

3. Ruždijić Adil, prof. (savjetnik za razrednu nastavu, uža specijalnost matematika),

4. Delić Hasan (savjetnik za razrednu nastavu, uža specijalnost matematika),

5. Bukarica Vaso, prof. (savjetnik za razrednu nastavu, uža specijalnost sh/hs.jezik),

6. Sarajkić Anka (savjetnik za razrednu nastavu),

7. Semanić Bešir (savjetnik za razrednu nastavu, uža specijalnost PPD),

8. Muhamedagić Husein (savjetnik za razrednu nastavu),

9. Vignjević Čedomir (savjetnik za razrednu nastavu, uža specijalnost matematika),

10. Zorić Dragutin, prof. (savjetnik za razrednu nastavu, uža specijalnost sh/hs. jezik),

11. Ramić Osman, prof. (savjetnik za razrednu nastavu, uža specijalnost PPD),

12. Soleša Branko, prof. (savjetnik za razrednu nastavu, uža specijalnost matematika),

13. Hajrulahović Ekrem, prof. (savjetnik za razrednu nastavu),

14. Šantić Zrinko, prof. (savjetnik za razrednu nastavu),

15. Šabanac Jasminka, prof. (savjetnik za razrednu nastavu),

16. Mihić Alojz, prof. (savjetnik za razrednu nastavu),

\subsubsection{Odsjek za pedagoško-psihološka pitanja}

1. Šturn Viktor (savjetnik za školsku i pedagošku dokumentaciju),

2. Selić Mikica, prof (savjetnik za stručno usavršavanje nastavnika),

3. Petrović Tihomir (savjetnik za stručno usavršavanje nastavnika),

4. Markovinović Radmila, prof ( savjetnik za pedagoška pitanja), 
5. Vučković Nikola, prof (savjetnik za organizaciju rada),

6. Petrov Slobodan, prof (savjetnik za organizaciju rada).

\section{ZAKLJUČAK}

Cjelokupna djelatnost Prosvjetno-pedagoškog zavoda Bihać može se prikazati u četiri tematska kruga:

1. Uvid u odgojno-obrazovni rad,

2. Analitička i stručno-istraživačka djelatnost,

3. Stalno stručno usavršavanje,

4. Saradnja sa organizacijama.

U procesu decentralizacije i demokratizacije društvenih odnosa i postepenog uvođenja samoupravljanja u sferu obrazovanja, donesen je prvi Zakon o prosvjetno-pedagoškoj službi (SL. NR BiH 50/60). Na osnovu tog zakona formirani su Republički zavod za unapređivanje školstva i prosvjetno-pedagoški zavodi, među kojima, za područje Bihaćkog sreza i Prosvjetno-pedagoški zavod u Bihaću. Ovim zakonom utemeljena je prosvjetno-pedagoška služba radi proučavanja i unapređivanja odgojno-obrazovnog rada u odgojno-obrazovnim ustanovama osnovnog i srednjeg obrazovanja. Jedan od važnih zadataka službe je bio nadzor nad izvršavanjem propisa o organizaciji i radu odgojno-obrazovnih ustanova.

Zakonom o prosvjetno-pedagoškoj službi iz 1964. godine (SL. SR BiH 42/64) unesene su novine u organizaciji i mogućnost osnivanja općinskih zavoda, navedeni su materijalni, kadrovski i finansijski uslovi za osnivanje zavoda i preciznije propisana stručna sprema prosvjetnih savjetnika. Na osnovu ovog zakona nastavio je rad Zavod za unapređivanje školstva, a Prosvjetno-pdagoški zavod u Bihaću pod nazivom Sreski prosvjetno-pedagoški zavod Bihać. Na poslovima službe radile su i posebne grupe za vršenje određenih poslova pri skupštinama opština. U vremenu od 1964. do 1968. godine Zavod je, u odnosu na prethodni period, kadrovski ojačao.

Zbog promjena u društveno-ekonomskom sistemu (prestanak funkcije srezova, jačanje komunalnog sistema, formiranje osnovnih zajednica obrazovanja), ali $\mathrm{i}$ zbog usitnjenosti $\mathrm{u}$ organizaciji neracionalne i kadrovski nekompletne službe te potreba odgojnoobrazovnog sistema, godine 1968. donesen je Zakon o prosvjetnopedagoškoj službi (SL. SR BiH 14/68), kojim se ukidaju postojeći 
zavodi. Na osnovi ovog zakona formiraju se Republički prosvjetnopedagoški zavod i regionalni, prosvjetno-pedagoški zavodi. Ukida se Sreski prosvjetno-pedagoški zavod i formira se Prosvjetno-pedagoški zavod u Bihaću za područje općina Bihać, Bos. Krupa, Cazin, Velika Kladuša. Godine 1969. područje djelovanja Zavoda se proširuje na općinu Bos. Petrovac, a 1973. na općine Drvar i Bos. Grahovo. Uslovi za formiranje i djelovanje Zavoda su poštreni i jasnije precizirani, kako kadrovski (savjetnici za razrednu nastavu, za sve općeobrazovne predmete i vaspitna područja, za stručne predmete, za pedagoška, psihološka, sociološka i druga pitanja) tako i materijalni (prostor, biblioteka, pedagoška dokumentacija i oprema), zahtijevalo se da savjetnici imaju, pored ostalih uslova, visoku stručnu spremu, osim za razrednu nastavu gdje su savjetnici mogli biti i sa višom stručnom spremom.

Zbog obimnosti poslova Zavod je bio prisiljen da u 1972 . godini angažira veći broj spoljnih saradnika. Njihova pomoć je bila neophodna prilikom obavljanja pregleda u odgojno-obrazovnim ustanovama na poslovima vrednovanja rada škola, izradi analiza o rezultatima, testiranja učeničkih znanja, održavanju seminara, savjetovanja, predavanja i dr. Bili su to prosvjetni savjetnici iz Republičkog prosvjetno-pedagoškog zavoda (H. Bezdrob, A. Beljkašić, M. Božanović), zatim banjalučkog Prosvjetno-pedagoškog zavoda (ing. mašinstva M. Domazet), elekt. ing. R. Misita iz Zavoda za izdavanje udžbenika Sarajevo, zatim N. Filipović, prof. Filozofskog fakulteta u Sarajevu, i dr. U 1974. godini Zavod je bio kostituisan kao samostalna odgojno-obrazovna ustanova kod Okružnog suda u Banjoj Luci.

Na osnovu Zakona o unapređivanju vaspitno-obrazovnog rada, u periodu od 1983. do 1988. godine transformira se Prosvjetnopedagoški zavod u Bihaću u Zavod za unapređivanje vaspitnoobrazovnog rada.

U periodu od 1988. do 1992. godine Zavod za unapređivanje odgojno-obrazovnog rada u Bihaću se tarnsformira i nastavlja svoju djelatnost kao Međuopćinski pedagoški zavod i kao takav djeluje sve do 1997. godine kada se Zavod ponovno ukida. U periodu od 1997. do 2000. godine Zavod je bio pripojen Ministarstvu obrazovanja, a od 2000. godine djeluje kao samostalna ustanova pod imenom Pedagoški zavod. 
Mora se dodati i to da je Zavod, bez obzira na rat 1992. godine, nastavio sa svojim radom iako su uslovi bili veoma teški. Prosvjetni savjetnici su, bez obzira na ratna događanja, uspjeli organizovati i posjete pojedinim školama. Zavod je odigrao veliku ulogu kad su u pitanju kontakti sa školama i nastavnicima u cilju pružanja pravovremenih informacija o planiranju, programiranju, pripremanju, radu slobodnih aktivnosti i drugim značajnim pitanjima. Ovo sve govori u prilog činjenici da Pedagoški zavod u Bihaću, kako danas nosi naziv, ima, dugu i uspješnu historiju.

\section{LITERATURA}

\section{Knjige}

Biščević i sar. (1982) Bihać. Beograd, Beogradski izdavačko-grafički zavod.

Good i Scates (1967) Metode istraživanja u pedagogiji, psihologiji i sociologiji. Rijeka, Otokar Keršovani.

Izvještaji o radu PPZ-a Bihać od 1963. do1992. godine.

Izvještaj o djelatnosti Prosvjetno-pedagoškog zavoda Bihać s prijedlogom koncepcije rada, Zavoda za unapređivanje vaspitno-obrazovnog rada Bihać u skladu sa zahtjevima, Zakona o unapređivanju vaspitno-obrazovnog rada (1982), Bihać, Prosvjetno-pedagoški zavod Bihać.

Mahmutović Džafer (2001) Stari Bihać. Bihać, Grafičar.

Mužić Vladimir (1977) Metodologija pedagoškog istraživanja. Sarajevo, OOUR Zavod za udžbenike.

Plan razvoja za period od 1981. do 1985. godine (1980), Bihać, SIZ osnovnog obrazovanja i vaspitanja.

Programi rada PPZ-a Bihać od 1963. do 1992. godine

- (1990) Prostorni plan općine Bihać 1986-2005. godine. Banjaluka, Skupština općine Bihać - Urbanistički zavod, Banjaluka.

Ramić, O. i Ćatić, R. (1998) Osnovnoškolska pedagogija. Zenica, Pedagoška akademija.

\section{Časopisi:}

Bajić Ljubivoje (1985) Uloga poslovodnog organa, prosvjetnog savjetnika i prosvjetnog inspektora u unošenju inovacija u nastavu, Naša škola, broj 1-2/85, str. 100-107.

Odgojno-obrazovni sistem u novim prilikama - Prvi kongres pedagoga $\mathrm{BiH}$ (1990), Sarajevo, Naša škola.

Pantić Drago (1979) Zadaci prosvjetnog savjetnika za pedagoško-psihološku službu, Naša škola, br. 7-8/79, str. 523-529. 
Palov Mihajlo (1957) Prosvjetni inspektor i proučavanje pedagoškog iskustva, Naša škola, br. 9-10/57, str.376-383.

Pedagogija u samoupravnom socijalističkom društvu - Prvi kongres pedagoga Hrvatske (1980), Zagreb, Pedagoško-književni zbor.

Pedagogija - Peti kongres pedagoga Jugoslavije (1982), Sarajevo, Savez pedagoških društava Jugoslavije.

Svrdlin Đuro (1989) Stručno usavršavanje prosvjetnih savjetnika primarni uslov uspješnijeg rada pedagoških zavoda, Naša škola, br. 7-8/89, str. 295-306.

Vaspitanje i rad - Četvrti kongres pedagoga Jugoslavije (1977), Beograd.

Rječnici i enciklopedije:

Franković i sar. (1963) Enciklopedijski rječnik pedagogije, Zagreb, Matica Hrvatska.

Potkonjak, N. i Šimleša, P. (1989) Pedagoška enciklopedija, Beograd, Zavod za udžbenike i nastavna sredstva.

\section{Zakoni:}

Zakon o prosvjetno-pedagoškoj službi, Službeni list NR BIH, broj 50/60. Zakon o prosvjetno-pedagoškoj službi, Službeni list SR BIH, broj 42/64. Zakon o prosvjetno-pedagoškoj službi, Službeni list SR BIH, broj 14/68. Zakon o prosvjetno-pedagoškoj službi, Službeni list SR BIH, broj 10/73. Zakon o prosvjetnoj inspekciji, Službeni list SR BIH, broj 39/73.

Zakon o stalnom stručnom usavršavanju nastavnika, Službeni list SR BIH, broj 6/76. 
SEBILA HASKIĆ, B.A.

\section{WORK OF EDUCATIONAL INSTITUTE IN BIHAĆ FROM 1960 TO 1992}

\section{SUMMARY}

An overview of activities of Educational Institute in Bihać from its foundation in 1960 to 1992 enabled us to have a more complete insight into its purpose and teaching procedure. In regard to fact that Educational institutes are there to view and evaluate results of work of all educational institutions from nursery to secondary schools, which caused the wish in me to research its role and contribution to the area of education and teaching.

The goal of this research is theoretical analyzing of institute's activities in Bihac since foundation in 1960 to 1992. Attention was focused primarily on chronological outline of institute's work, its transformation, professional work and pedagogues who worked in Educational institute during this period. 
سبيلة هاسكيتش، أستاذة علم التربية

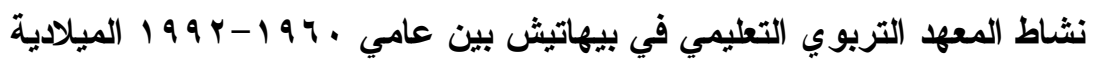
الملخص

بيساهم عرض نشاط المعهد التزبوي التعليمي في بيهاتش بين عامي .994-199 الميلادية في توضيح دوره في العملية التعليمية. بما أن الهدف الأول من المعاهد التربوية

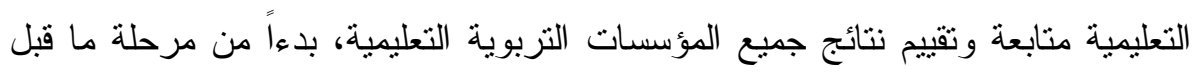

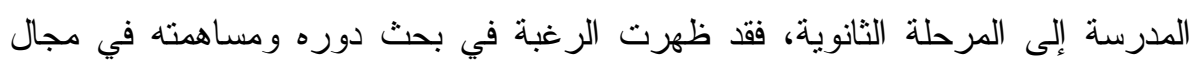
التزبية و التعليم.

الهدف من هذا البحث هو در اسةٌ نظريةٌ لنشاط المعهد التربوي التعليمي في بيهانش بين عامي • 97 199-199 الميلادية.

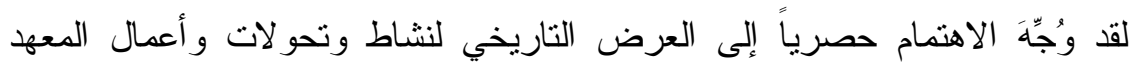
التخصصية و التأهيلية، إضافة إلى أساتذة علم التربية العاملين في المعهد التربوي التعليمي في بيهاتش في نلك الفترة. 